ISSN 1997-5902

\title{
Effect of thidiazuron on in vivo shoot proliferation of popular banana (Musa spp. L) cultivars in Tanzania
}

\author{
Theodosy J. Msogoya ${ }^{\star *}$ and Juliana Mwakisitu² \\ ${ }^{1}$ Sokoine University of Agriculture, P.O Box 3005 Morogoro, Tanzania \\ 2Ministry of Agriculture, Food Security and Cooperatives, Dar es Salaam, Tanzania \\ * Corresponding author: Email: timsogoya@yahoo.com
}

Original submitted in on $2^{\text {nd }}$ July 2014. Published online at www.m.elewa.org on 30th September 2014. http://dx.doi.org/10.4314/jab.v81i1.1

\begin{abstract}
Objective: Thidiazuron (TDZ) is a diphenyl urea-based cytokinin, which is non-degradable and persistent in plant tissues. The effect of these TDZ properties on in vivo banana proliferation when deshealthed corms are temporarily dipped in such growth regulator is unknown. The objective of this study was to evaluate the effect of temporary treatments with TDZ of deshealthed banana corms on in vivo sucker multiplication.

Methodology and Results: The study was comprised of a split plot experiment in a randomized complete design with three replications each replication with 10 corms. The main plot factor was banana cultivars (Mtwike, Mzuzu and Bukoba) while the sub-plot factor was TDZ concentrations (0.5, 1.0, 2.0 and $3.0 \mathrm{mg} / \mathrm{l})$. Moistened sawdust was steam-sterilized for 45 minutes and then filled for cooling in wooden propagators. Banana suckers were cleaned to remove roots and surface-sterilized for 15 seconds. The sterilized corms were deshealthed to expose axillary buds and decorticated to suppress the apical meristems. These corns were each dipped in TDZ at $0.5,1.0,2.0$ and $3.0 \mathrm{mg} / \mathrm{l}$ for 12 hours and then planted into the sterilized sawdust media in the propagators. Results showed that the number of shoots per corm significantly $(P<0.05)$ increased as TDZ concentration increased from 0.0 to $2.0 \mathrm{mg} / \mathrm{l}$ but decreased as TDZ increased to $3.0 \mathrm{mg} / \mathrm{l}$. The number of leaves per sucker significantly $(P<0.05)$ decreased as TDZ concentration increased from 0.0 to $3.0 \mathrm{mg} / \mathrm{l}$. Conversely, corms treated with TDZ at $2.0 \mathrm{mg} / \mathrm{l}$ produced suckers with the largest number of leaves of 4.9 per sucker followed by corms treated with TDZ at 1.0, 3.0 and $0.5 \mathrm{mg} / \mathrm{l}$ with $4.5,4.3$ and 3.3 leaves per sucker, respectively. Banana cultivars had a significant $(P<0.05)$ effect on the number of shoots per corm where banana cv. Bukoba produced the largest number of shoots of 6.4 per corm while banana cv. Mtwike and Mzuzu produced 2.3 and 2.9 shoots per corm, respectively.

Conclusion and Application: The findings from this study provide evidence that in vivo shoot multiplication rates and sucker growth of banana cv. Mzuzu, Bukoba and Mtwike can be increased by dipping for 12 hours deshealthed corms in TDZ solution at $2.0 \mathrm{mg} / \mathrm{l}$. The low in vivo multiplication rates of banana cv. Mtwike and Mzuzu underscore the need for further studies to determine alternative best cytokine-based growth regulators. Key words: Thidiazuron, in vivo proliferation, Sucker growth, Banana.
\end{abstract}

\section{INTRODUCTION}

In vivo macropropagation is an alternative technique for mass production of banana planting materials under in vivo conditions (Kwa, 2003; Njukwe et al.,
2005). The technique involves disinfecting, deshealthing banana corms to expose axillary buds and decorticating the apical meristem to suppress 
apical dominance (Kwa, 2003; Njukwe et al., 2005; Kindimba and Msogoya, 2014). Compared to in vitro propagation, this technique provides in a short period pest-free plantlets (Njukwe et al., 2005; Kwa, 2003) and has the potential of producing 50 - 60 shoots per corm in 4 - 5 months (Baiyeri and Aba, 2004). In this technique, banana corms are planted in a sterile sawdust initiation media either without or with treatment of benzlyamimopurine (Baiyeri and $\mathrm{Aba}$, 2004). This technique has shown better results when corms from flowered banana plants and maiden suckers are used (Baiyeri and Ajayi, 2000; Kwa, 2003). The inability of axillary buds from small banana suckers to sprout under in vivo macropropagation is associated with the high apical dominance caused by high auxin levels (Arinaitwe et al., 2000). Auxins work antagonistically with cytokinins, and thus an application of the later suppresses apical dominance and consequently promotes proliferation of axillary buds (Naseem, and Dandekar, 2012). In vivo macropropagation combined with an application of BAP in cavities of decorticated corms induced more sprouting of axillary buds in banana (Singh et al., 2011). Moreover, a temporary dipping of deshealthed and decorticated corms in BAP at $1.5 \mathrm{mg} / \mathrm{l}$ resulted to the highest in vivo proliferation of 17.11 suckers per corm in plantain cv." Itoke Sege" (Kindimba and

\section{MATERIALS AND METHODS}

Materials: Three banana cultivars were used in this study namely "Mtwike" (Cavendish cv. Grande naine), "Mzuzu" (French plantain) and Bukoba (East African highland banana). Banana suckers of about $100 \mathrm{~cm}$ tall and $15 \mathrm{~cm}$ collar diameter were collected from farmers. The suckers were headed back $30 \mathrm{~cm}$ and sterilized by dipping them into hot water at $100{ }^{\circ} \mathrm{C}$ for 15 seconds. The sterilized corms were deshealthed to expose the axillary buds and the exposed axillary buds were wounded by cutting them transversely to stimulate multiple sprouting. The apical meristem of each corm was destroyed by decortication to overcome the apical dominance. Sawdust sourced locally was used as an initiation media. The sawdust was steamsterilized at $100{ }^{\circ} \mathrm{C}$ for 45 minutes and then was poured in propagators for cooling. A propagator with a dimension of $3.0 \mathrm{~m} \times 1.0 \mathrm{~m} \times 0.5 \mathrm{~m}$ was constructed by using soft timbers.
Msogoya, 2014). Thidiazuron (TDZ) is a diphenyl urea based cytokinin growth regulator, which is nondegradable by cytokinin-oxidase enzymes (Makara et al., 2010). Furthermore, TDZ has long residual effects, increases the biosynthesis of endogenous adenine-based cytokinins and enhances nutrient uptake and assimilation in plants (Guo, et al. 2011). This growth regulator induces shoot proliferation in plant species that respond poorly to 6benzylaminopurine supplemented growth medium (Huetteman and Preece, 1993). In vitro shoot proliferation rates of both recalcitrant and responsive banana genotypes increased with TDZ concentration from 0.01 to $2.0 \mathrm{mg} / \mathrm{l}$ (Arinaitwe et al., 2000) while TDZ concentrations above $2.0 \mathrm{mg} / \mathrm{l}$ or below 0.01 $\mathrm{mg} / \mathrm{l}$ reduced in vitro shoot proliferation and suppressed shoot elongation in banana (Crouch et al., 1998). It is hypothesized that the high residual effect of TDZ would increase in vivo proliferation rates when deshealthed and decorticated banana corms are temporarily dipped in a solution of such growth regulator. Unfortunately, studies on the effect of temporary TDZ treatments on banana in vivo macropropagation rates are scanty. The objective of this study was to determine the effect of temporary TDZ treatments on in vivo proliferation rates and shoot growth of popular banana cultivars in Tanzania.

Experimental design: The experiment was set as a split plot arrangement in a randomized complete block design with three replications. A replication consisted of 10 corms of each cultivar. Banana cultivars (Mtwike, Mzuzu and Bukoba) were the main plot factor while TDZ concentrations $(0.5,1.0,2.0$ and $3.0 \mathrm{~g} / \mathrm{l})$ were the sub-plot factor. The deshealthed and decorticated banana corms were soaked for 12 hours into each TDZ concentration. The TDZ treated corms were planted into moistened sawdust filled in the propagators. The propagators were placed under a plastic tunnel with temperature of 25 - 30 ${ }^{\circ} \mathrm{C}$. The remaining TDZ solution for each concentration was poured onto the sawdust at $6 \mathrm{l} / \mathrm{m}^{3}$ of the propagator. Irrigation was carried out twice per week while poly-feed starter fertilizer (N-P-P at $19-19-19)$ at a concentration of $0.5 \mathrm{~g} / \mathrm{l}$ of water was applied after two months at 6 litres of solution per $\mathrm{m}^{2}$. 
Data collection and analysis: Data collection included the number of days to first shoot emergence, number of sprouted buds per corm, number of shoots per bud, number of shoots per corm and shoot size based on height, collar diameter and number of leaves per shoot.

\section{RESULTS}

Effect of TDZ concentration on in vivo multiplication and sucker growth: The number of sprouted buds per corm, number of shoots per bud and number of shoots per corm significantly $(P<0.05)$ increased as TDZ concentration increased from 0.0 to $2.0 \mathrm{mg} / \mathrm{l}$ but decreased as TDZ increased to $3.0 \mathrm{mg} / \mathrm{l}$ (Table 1). Thidiazuron at $2.0 \mathrm{mg} / /$ resulted in the largest number of sprouted buds of 2.9 buds per corm followed TDZ at 1.0,
The collected data were subjected to analysis of variance using GenStat Statistical Programme $12^{\text {th }}$ Edition (Rayne et al., 2009). Treatment mean separation was carried out based on Student-Newman-Keuls at $P<5 \%$.

3.0 and $0.5 \mathrm{mg} / \mathrm{l}$ with $2.6,2.5$ and 1.7 sprouted buds per corm, respectively. Similarly, TDZ at $2.0 \mathrm{~g} / \mathrm{l}$ resulted in the largest number of shoots of 2.0 per bud followed by TDZ at $3.0,1.0$ and $0.5 \mathrm{mg} / \mathrm{l}$ with $1.8,1.5$ and 1.2 shoots per bud, respectively. Overall, TDZ at $2.0 \mathrm{mg} / /$ resulted in the largest number of shoots per corm of 6.3 shoots followed by TDZ at 3.0, 1.0 and $0.5 \mathrm{mg} / \mathrm{l}$ with $4.6,4.0$ and 1.9 shoots per corm, respectively.

Table 1: Effect of TDZ concentration on in vivo multiplication of different banana cultivars

\begin{tabular}{|c|c|c|c|c|}
\hline $\begin{array}{l}\text { TDZ conc. } \\
\text { (mg/l) }\end{array}$ & $\begin{array}{l}\text { Days to } 1^{\text {st }} \text { shoot } \\
\text { emergence }\end{array}$ & $\begin{array}{l}\text { No. of sprouted } \\
\text { buds/corm }\end{array}$ & $\begin{array}{l}\text { No. of shoots } \\
\text { per bud }\end{array}$ & No. of shoots per corm \\
\hline 0.5 & 29.4 & $1.7^{\mathrm{a}}$ & $1.2^{\mathrm{a}}$ & $1.9^{a}$ \\
\hline 1.0 & 25.0 & $2.6^{b}$ & $1.5^{\mathrm{ab}}$ & $4.0^{\mathrm{b}}$ \\
\hline 2.0 & 28.8 & $2.9^{b}$ & $2.0^{\mathrm{b}}$ & $6.3^{c}$ \\
\hline 3.0 & 28.5 & $2.5^{\mathrm{ab}}$ & $1.8^{\mathrm{ab}}$ & $4.6^{\mathrm{bc}}$ \\
\hline LSD & 3.7 & 0.6 & 0.6 & 1.5 \\
\hline F-test & ns & $\mathrm{s}$ & $\mathrm{s}$ & $\mathrm{s}$ \\
\hline S.E & 3.8 & 0.6 & 0.58 & 1.5 \\
\hline CV (\%) & 13.9 & 20.4 & 24.9 & 25.5 \\
\hline
\end{tabular}

Means followed by the same letters(s) within the column are not significant different at $P<5 \%$ based on StudentNewman-Keuls. $n s=$ not significant and $s=$ significant at $P<5 \%$.

Sucker collar diameter and number of leaves per sucker significantly $(P<0.05)$ decreased as TDZ concentration increased from 0.0 to $3.0 \mathrm{mg} / \mathrm{l}$ (Table. 2). Corms treated with TDZ at $0.5 \mathrm{mg} / \mathrm{l}$ produced suckers with the biggest collar diameter of $2.2 \mathrm{~cm}$ followed by corms treated with TDZ at 1.0, 2.0 and $3.0 \mathrm{mg} / \mathrm{l}$ with shoot collar diameter of
$1.7,1.6$ and $1.6 \mathrm{~cm}$, respectively. However, corms treated with TDZ at $2.0 \mathrm{mg} / \mathrm{l}$ produced suckers with the largest number of leaves of 4.9 per sucker followed by corms treated with TDZ at 1.0, 0.5 and $3.0 \mathrm{mg} / \mathrm{l}$ with $4.5,3.3$ and 4.3 leaves per sucker, respectively.

Table 2: Effect of TDZ concentration on growth of in vivo derived banana suckers

\begin{tabular}{llll}
\hline TDZ conc. (mg/l) & Sucker height $(\mathrm{cm})$ & Sucker diameter $(\mathrm{cm})$ & No. of leaves per sucker \\
\hline 0.5 & 15.2 & $2.2^{\mathrm{b}}$ & $3.3^{\mathrm{a}}$ \\
1.0 & 15.5 & $1.7^{\mathrm{ab}}$ & $4.5^{\mathrm{b}}$ \\
2.0 & 15.1 & $1.6^{\mathrm{a}}$ & $4.9^{\mathrm{b}}$ \\
3.0 & 15.5 & $1.6^{\mathrm{a}}$ & $4.3^{\mathrm{ab}}$ \\
LSD & 2.9 & 0.4 & 0.84 \\
F-test & $\mathrm{ns}$ & $\mathrm{S}$ & $\mathrm{S}$ \\
SE & 3 & 0.4 & 0.86 \\
CV $(\%)$ & 19.8 & 22.8 & 20.2 \\
\hline
\end{tabular}

Means followed by the same letters(s) within the column are not significant different at $5 \%$ level based on StudentNewman-Keuls. $n s=$ not significant and $s=$ significant at $P<5 \%$. 


Msogoya et Mwakisitu. J. Appl. Biosci. 2014. Effect of thidiazuron on in vivo shoot proliferation of
popular banana cultivars in Tanzania

Effect of banana cultivars on in vivo multiplication and sucker growth: Banana cultivar had a significant $(P$ $<0.05$ ) effect on the number of sprouted buds per corm, number of shoots per bud and number of shoots per corm (Table 3). In banana cv. Bukoba, 3.2 buds sprouted per corm while 1.7 and 2.4 buds sprouted per corm in banana cv. Mtwike and Mzuzu, respectively. Banana cv. Bukoba also produced 2.0 shoots per bud while cv. Mtwike and cv. Mzuzu produced 1.4 and 1.6 shoots, respectively. Moreover, cv. Bukoba produced the largest number of shoots of 6.4 per corm compared with banana cv. Mtwike and Mzuzu with 2.3 and 2.9 shoots per corm, respectively. Banana cultivar had no significant $(P<0.05)$ effect on shoot height, collar diameter and number of leaves per sucker (Table 4).

Table 3: Effect of banana cultivar on in vivo shoot proliferation

\begin{tabular}{lcccc}
\hline Cultivar & $\begin{array}{c}\text { No. of days to } 1^{\text {st }} \\
\text { shoot sprouting }\end{array}$ & $\begin{array}{c}\text { No. of sprouted } \\
\text { buds per corm }\end{array}$ & $\begin{array}{c}\text { No. of shoots per } \\
\text { bud }\end{array}$ & No. of shoots per corm \\
\hline Mtwike & 25.0 & $1.7^{\mathrm{a}}$ & $1.4^{\mathrm{a}}$ & $2.3^{\mathrm{a}}$ \\
Mzuzu & 27.2 & $2.4^{\mathrm{ab}}$ & $1.6^{\mathrm{ab}}$ & $2.9^{\mathrm{a}}$ \\
Bukoba & 23.2 & $3.2^{\mathrm{b}}$ & $2.0^{\mathrm{b}}$ & $6.4^{\mathrm{b}}$ \\
LSD & 5.4 & 0.6 & 0.46 & 1.67 \\
F-test & $\mathrm{ns}$ & $\mathrm{S}$ & $\mathrm{s}$ & $\mathrm{S}$ \\
S.E & 2.4 & 0.3 & 0.5 & 0.7 \\
CV (\%) & 8.6 & 11.5 & 12.2 & 17.5 \\
\hline
\end{tabular}

Means followed by the same letters(s) within the column are not significant different at $5 \%$ level based on StudentNewman-Keul. ns $=$ not significant and $s=$ significant at $P<5 \%$.

Table 4: Effect of banana cultivars on growth of in vivo derived multiplication suckers

\begin{tabular}{lccc}
\hline Cultivar & Sucker height $(\mathbf{c m})$ & $\begin{array}{c}\text { Sucker diameter } \\
\text { (cm) }\end{array}$ & No. of leaves per sucker \\
\hline Mtwike & 14.11 & 1.71 & 4.05 \\
Mzuzu & 15.98 & 1.75 & 4.18 \\
Bukoba & 16.04 & 1.88 & 4.52 \\
L.S.D & 2.4 & 0.4 & 0.7 \\
F-test & $\mathrm{ns}$ & $\mathrm{ns}$ & $\mathrm{ns}$ \\
S.E & 3.0 & 0.18 & 0.34 \\
CV $(\%)$ & 6.9 & 10.3 & 7.9 \\
\hline
\end{tabular}

$n s=$ not significant at $P<0.05$.

Effect of interaction of cultivar and thidiazuron on in vivo sucker multiplication and growth: Banana $\mathrm{Cv}$. Mzuzu - TDZ interaction had a significant $(P<0.05)$ effect on the number of shoots per corm (Table 5). Banana cv. Mzuzu produced the largest number of shoots of 10.4 and
5.3 per corm in TZD at 2.0 and $3.0 \mathrm{mg} / \mathrm{l}$ followed by $\mathrm{cv}$. Bukoba with 5.3 and 5.2 shoots per corm in TDZ at 2.0, $3.0 \mathrm{mg} / \mathrm{l}$, and $\mathrm{cv}$. Mtwike with 3.1. and 3.2 shoots per corm in TDZ at 2.0 and $3.0 \mathrm{mg} / \mathrm{l}$.

Table 5: Interaction effect of banana cultivar and Thidiazuron concentrations on in vivo sucker proliferation

\begin{tabular}{lcccc}
\hline $\begin{array}{l}\text { Cultivar } \times \text { TDZ conc. } \\
\text { Interaction mg/l }\end{array}$ & $\begin{array}{c}\text { No. of days of } \text { st }^{\text {st }} \\
\text { sucker sprouting }\end{array}$ & $\begin{array}{c}\text { No of buds } \\
\text { per corm }\end{array}$ & $\begin{array}{c}\text { No. of suckers } \\
\text { per bud }\end{array}$ & $\begin{array}{c}\text { No. of suckers per } \\
\text { corm }\end{array}$ \\
\hline Bukoba $\times 0.5$ & 24.9 & 1.2 & 1.6 & $1.9^{\text {cd }}$ \\
Bukoba $\times 1.0$ & 25.0 & 2.5 & 1.2 & $3.2^{\text {cd }}$ \\
Bukoba $\times 2.0$ & 26.6 & 2.7 & 1.7 & $5.2^{\text {bc }}$ \\
Bukoba $\times 3.0$ & 24.4 & 2.8 & 1.8 & $5.3^{\text {bc }}$ \\
Mtwike $\times 0.5$ & 33.7 & 1.3 & 1.0 & $1.3^{\mathrm{d}}$ \\
Mtwike $\times 1.0$ & 26.6 & 1.5 & 1.0 & $1.6^{\mathrm{d}}$ \\
Mtwike $\times 2.0$ & 32.1 & 1.9 & 1.5 & $3.1^{\text {cd }}$ \\
\hline
\end{tabular}




\begin{tabular}{lcccc}
$\begin{array}{l}\text { Msogoya et Mwakisitu. J. Appl. Biosci. } \\
\text { popular banana cultivars in Tanzania }\end{array}$ & Effect of thidiazuron on in vivo shoot proliferation of \\
\multicolumn{4}{l}{} \\
\hline Mtwike x 3.0 & 32.3 & 2.0 & 2.0 & $3.2^{\text {cd }}$ \\
Mzuzu x 0.5 & 29.4 & 2.3 & 1.2 & $2.7^{\text {cd }}$ \\
Mzuzu x 1.0 & 23.6 & 3.6 & 2.1 & $7.2^{\mathrm{b}}$ \\
Mzuzu x 2.0 & 27.1 & 3.9 & 2.9 & $10.5^{\mathrm{a}}$ \\
Mzuzu x 3.0 & 28.1 & 2.5 & 1.9 & $5.3^{\mathrm{bc}}$ \\
LSD & 7.1 & 0.9 & 0.8 & 2.5 \\
F-test & $\mathrm{ns}$ & $\mathrm{ns}$ & $\mathrm{ns}$ & $\mathrm{S}$ \\
S.E & 2.4 & 0.3 & 0.3 & 0.8 \\
CV (\%) & 14.3 & 23.6 & 21.9 & 25.5 \\
\hline
\end{tabular}

Means followed by the same letters(s) within the column are not significant at different $5 \%$ level based on StudentNewman-Keuls. $n s=$ not significant and $s=$ significant at $p<5 \%$.

The interaction of banana cultivars and TDZ concentrations had no significant $(P<0.05)$ effect on

sucker height, sucker collar diameter and number of leaves per sucker (Table 6).

Table 6: Interaction effect of banana cultivar and Thidiazuron concentrations on growth of in vivo multiplication derived suckers

\begin{tabular}{lccc}
\hline Cultivar x TDZ conc. Interaction mg/l & $\begin{array}{c}\text { Sucker height } \\
(\mathbf{c m})\end{array}$ & $\begin{array}{c}\text { Sucker diameter } \\
(\mathbf{c m})\end{array}$ & $\begin{array}{c}\text { No. of leaves per } \\
\text { sucker }\end{array}$ \\
\hline Bukoba $\times 0.5$ & 16.2 & 2.2 & 3.6 \\
Bukoba $\times 1.0$ & 15.3 & 1.5 & 4.6 \\
Bukoba $\times 2.0$ & 15.1 & 1.8 & 5.0 \\
Bukoba $\times 3.0$ & 14.1 & 1.6 & 4.0 \\
Mtwike $\times 0.5$ & 11.7 & 2.0 & 3.4 \\
Mtwike $\times 1.0$ & 15.8 & 1.9 & 4.4 \\
Mtwike $\times 2.0$ & 14.0 & 1.3 & 4.6 \\
Mtwike $\times 3.0$ & 14.2 & 1.7 & 4.4 \\
Mzuzu $\times 0.5$ & 16.6 & 2.1 & 3.3 \\
Mzuzu $\times 1.0$ & 15.3 & 1.7 & 4.2 \\
Mzuzu $\times 2.0$ & 13.6 & 1.6 & 4.2 \\
Mzuzu $\times 3.0$ & 16.0 & 1.6 & 4.3 \\
LSD & 5.3 & 0.7 & 1.5 \\
F-test & $n \mathrm{~ns}$ & $\mathrm{~ns}$ & $\mathrm{~ns}$ \\
S.E & 1.8 & 0.2 & 0.5 \\
CV (\%) & 22.2 & 23.5 & 22.8 \\
\hline
\end{tabular}

$n s=$ not significant and $s=$ significant at $P<0.05)$.

\section{DISCUSSION AND CONCLUSION}

Effects of TDZ on banana in vivo shoot proliferation and growth: In this study, the number of shoots increased from 1.9 to 6.3 shoots per corm as TDZ concentration increased from 0.5 to $2.0 \mathrm{mg} / \mathrm{l}$ but decreased to 4.6 shoots per corm as TDZ further increased to $3.0 \mathrm{mg} / \mathrm{l}$. This trend is in agreement with Arinaitwe et al. (2000) who also found that in vitro proliferation of banana cv. Ndiziwemiti (ABB) increased as TDZ concentration increased from 0.01 to $1.25 \mathrm{mg} / \mathrm{l}$. Similarly, Youmbi et al. (2006) reported higher in vitro proliferation in lower TDZ concentration ranging from 0.01 to $0.02 \mathrm{mg} / \mathrm{l}$. The in vivo multiplication rate reported in this study is relatively low and does not therefore demonstrate any benefits of residual effect of TDZ treatments. Comparatively, a temporary treatment of deshealthed corms of plantain cv. "Itoke Sege" in benzylaminopurine at $1.5 \mathrm{mg}$ /litre produced 17.11 in vivo suckers per corm (Kindimba and Msogoya, 2014). In the present study TDZ concentration from 0.5 to $2.0 \mathrm{mg} / \mathrm{l}$ increased in vivo shoot growth based on the number of leaves per shoots though the number of leaves per sucker decreased as TDZ concentration increased to $3.0 \mathrm{mg} / \mathrm{l}$. The trend in these results is in agreement with Gubuku et al. (2004) who also reported that in vitro shoot elongation increased as TDZ concentration increased from $0.01 \mathrm{mg} / \mathrm{l}$ to $0.22 \mathrm{mg} / \mathrm{l}$ but decreased when TDZ increased above $0.44 \mathrm{mg} / \mathrm{l}$. 
Similarly, Youmbi et al. (2006) reported an increasing number of leaves per in vitro shoot as TDZ concentration increased from 0.01 to $0.09 \mathrm{mg} / \mathrm{l}$. In this study banana $\mathrm{Cv}$. Bukoba exhibited the highest in vivo shoot proliferation rate followed by Mzuzu and Mtwike. Using banana cv. Kibuzi (AAA East Africa highland banana) and cv. Ndiziwemiti (ABB), Arinaitwe et al. (2000) also reported that in vitro proliferation rate depended on banana genomic groups and cultivars. According to Blakesley (1991) the differential responses to TDZ concentrations among banana genotypes is associated with their difference in cytokinin uptake, translocation to the meristematic region and degradation. Specifically, Youmbi et al. (2006) reported in vitro proliferation rate of 18.7 shoots per explant of banana (AAA) cv. Gross
Michel at TDZ concentration of $0.08 \mathrm{mg} / \mathrm{l}$ while banana (ABB) cv. Fougamou required TDZ concentration of 0.20 $\mathrm{mg} / \mathrm{l}$ to produce the same number of suckers per explant. To conclude, the findings from this study reveal that in vivo shoot multiplication of banana cv. Mzuzu, Bukoba and Mtwike can be increased by dipping for 12 hours deshealthed and decorticated corms in TDZ solution at $2.0 \mathrm{mg} / \mathrm{l}$. The response of banana to TDZ depends on cultivars where $\mathrm{cv}$. Bukoba provides the highest in vitro multiplication rate in TDZ at $2.0 \mathrm{mg} / \mathrm{l}$. The differential response among banana cultivars to TDZ concentrations underscores the need to determine alternative cytokinebased growth regulators for increasing in vivo multiplication of banana cv. Mzuzu and Mtwike.

\section{ACKNOWLEDGEMENT}

The authors are thankful to Ministry of Agriculture, Food Security and Cooperatives for financing this study.

\section{REFERENCES}

Arinaitwe, G., Rubaihayo, PR. and Magambo, MJS. (2000). Proliferation rate effects of cytokinins on banana (Musa spp) cultivars. Scienta Horticulturae 86: 13 - 21.

Baiyeri, KP. and Aba, SC. (2004). Response of Musa species to macro-propagation. I: Genetic and initiation media effects on number, quality and survival of plantlets at pre-nursery and early nursery stages. Dept. of Crop Science, University of Nigeria, Nsukka, Nigeria. African Journal of Biotechnology 4 (3), pp. 223-228.

Baiyeri, KP. and Ajayi, AR. (2000). Status and constraints of Musa spp. Production in a sub humid zone of Nigeria. Acta Horticulturae 540: 73 - 77.

Blakesley, D. (1991). Uptake and metabolism of 6benzyladenine in shoot proliferation of Musa and Rhododendron. Plant Cell, Tissue and Organ Culture 25: 69-74.

Crouch, JH., Vuylsteke, D. and Ortz, R. (1998).Perspectives on the application of biotechnology to assist the genetic enhancement of plantain banana (Musa spp.). Electronic Journal of Biotechnology 1:11-22.

Guo, B., Abbasi, BH., Zeb, A., Xu, LL. and Wei1, YH. (2011). Thidiazuron: A multi-dimensional plant growth regulator. African Journal of Biotechnology 10(45): 8984 - 9000.

Gubuku, H. and Pekmezcu, M. (2004). In vitro propagation of some new banana types (Musa spp.). Turk J Agric, 28: 355-361.
Huetteman, CA. and Preece, JE. (1993). Thidiazuron a potent cytokinin for woody plant tissue culture. Plant Cell, Tissue and Organ Culture 33: 105119.

Kindimba, GV and Msogoya, TJ. (2014). Effect of benzlyaminopurine on in vivo multiplication of Plantain (Musa spp. AAB) cv. 'Itoke sege'. Journal of Applied Biosciences 74: 6086-6090.

Kwa, M. (2003). Activation of latent buds and utilization of stem fragments for plants mass propagation in in vivo horticulture conditions. Fruits 58: 315 328.

Makara, AM., Rubaihayo, PR. and Magambo, MJS. (2010). Carry-over effect of thidiazuron on banana in vitro proliferation at different culture cycles and light incubation conditions. African Journal of Biotechnology 9 (21): 3079-3085.

Naseem, M. and Dandekar, T. (2012). The role of auxincytokinin antagonism in plant pathogen interactions. PLOS Pathog 8 (11): Site visited on 20 June 2013.

Njukwe, E., Tenkouano, A., Amah, D., Sadik, K., Muchunguzi, P., Nyine, M. and Dubois, T. (2005). Macro-propagation of banana and plantain. International Institute of Tropical Agriculture Training manual. 23pp.

Rayne, RW., Murray, DA., Harding, SA., Baird, BB. and Soutar, DM. (2009). GenStat for Windows (12th Edition). Introduction. VSN International, Hemel Hempstead. 
Msogoya et Mwakisitu. J. Appl. Biosci. 2014. Effect of thidiazuron on in vivo shoot proliferation of popular banana cultivars in Tanzania

Singh. HP., Uma, S., Selvarajan, R. and Karihaloo JL. (2011). Micro propagation for Production of Quality Banana Planting Material in Asia-Pacific. Asia-Pacific Consortium on Agricultural Biotechnology (APCoAB), New Delhi, India. 92pp.
Youmbi, E. Ella, B. and Tomekpe, K. (2006). Effect of thidiazuron on in vitro proliferation capacities of some banana (musa spp.) cultivars with weak multiplication potential. Akdeniz üniversitesi ziraat fakültesi dergisi 19(2): 255 - 259. 